\title{
Implementing sustainable food forests: Extracting success factors through a cross-case comparison
}

\author{
Stefanie Albrecht ${ }^{a *}$ \\ Leuphana University Lüneburg \\ Arnim Wiek b, c \\ Arizona State University
}

Submitted March 10, 2021 / Revised May 20 and June 27, 2021 / Accepted June 30, 2021 /

Published online December 21, 2021

Citation: Albrecht, S., \& Wiek, A. Implementing sustainable food forests: Extracting success

factors through a cross-case comparison. Journal of Agriculture, Food Systems, and Community

Development, 11(1), 183-200. https://doi.org/10.5304/jafscd.2021.111.019

Copyright (C) 2021 by the Authors. Published by the Lyson Center for Civic Agriculture and Food Systems. Open access under CC-BY license.

\begin{abstract}
Food forests are multistrata ecosystems that provide healthy food, livelihood opportunities, as well as social-cultural and environmental services. With these features, food forests address several problems industrial food systems cause. While the overall number of food forests is continuously increasing worldwide, the rate of uptake is still low. This study reconstructs in detail how different types of food forests $(n=7)$ were realized, mostly in Europe, with a focus on organization and management. Findings confirm and add to previous
\end{abstract}

\footnotetext{
a* Corresponding author: Stefanie Albrecht, Doctoral student, Center for Global Sustainability and Cultural Transformation, Leuphana University Lüneburg; Universitätsallee 1, 21335; Lüneburg, Germany; Stefanie.Albrecht@leuphana.de

b, c Arnim Wiek, Professor, School of Sustainability, Arizona State University, Tempe, AZ USA; and Guest Professor, Center for Global Sustainability and Cultural Transformation, Leuphana University Lüneburg, Lüneburg, Germany.
}

studies indicating that the successful implementation of food forests depends on long-term land access, sufficient start-up funds, and adequate farming and entrepreneurial know-how, among other factors. While these are not unique factors compared to other farm and food businesses, sustainable food forests face particular obstacles to secure them. This study offers guidance to food entrepreneurs, public officials, and activists on how to successfully implement food forests to realize their full sustainability potential.

\section{Keywords}

Food Forests, Forest Gardens, Food Economy, Food Entrepreneurship, Implementation Paths, Case Studies

\section{Funding Disclosure}

This research was made possible through the graduate school 'Processes of Sustainability Transformation' at Leuphana University Lüneburg, funded by the Robert Bosch Stiftung (12.5.F082.0021.0). 


\section{Introduction}

The conventional globalized food system causes negative externalities worldwide (Garnett, 2011; Rockström et al., 2020; Tilman \& Clark, 2014). Considering that climate tipping points are in reach (Lenton et al., 2019), sustainable food system solutions are urgently needed. Food forests are multifunctional ecosystems that might offer such a solution, or at least part of it, through a variety of services, including food provision, livelihoods, and environmental services, among others (Albrecht \& Wiek, 2021). We define a food forest as a coherent, multistrata space with a majority of edible perennial plants, a minimum size of 1 acre $(\sim 0.5 \mathrm{ha})$, and $10 \%$ canopy cover to provide forest-like ecosystem services and significant food production. We focus here on food forests as business or nonprofit endeavors that go beyond self-sufficiency. We define food forest managers as entrepreneurs, even if they often act through alternative markets and organizational modes, as they offer products or services to the public and generate an income from their activities.

Food forests have been developed and cared for by Indigenous people around the world for thousands of years (Ford \& Nigh, 2009; Kumar \& Nair, 2004). The number of 'modern' food forests worldwide has been steadily increasing since the 2000s, yet, the overall number is still small and the rate of uptake is low (Albrecht \& Wiek, 2021). This is due, in part, to a conflict of economic paradigms: food forests, particularly those with ambitious sustainability goals, are oriented toward long-term and optimally balanced co-benefits, while mainstream business culture pursues short-term profit maximization, which creates obstacles for the implementation of food forests under current economic conditions. A good share of food forests therefore have been created as nonprofit organizations, private side businesses, or public-private partnerships (Albrecht \& Wiek, 2021), including many (community) food forests on public urban sites (Konijnendijk \& Park, 2020; Vannozzi Brito \& Borelli, 2020). However, making them economically viable by generating sufficient income for maintenance and livelihoods often conflicts with the interest of public lease givers or community-oriented initiators, even if no profit is generated (Bukowski \&
Munsell, 2018). These food forests also often struggle with insufficient funding and over-reliance on volunteers. In addition to these barriers to general uptake, it seems reasonable to assume that the sustainability performance of food forests is also influenced by the specifics of the implementation process (available funding, practical farming know-how, etc.). While there is some empirical evidence that these challenges hamper the wider uptake of food forests in general (Belcher et al., 2005; Björklund et al., 2019) and the adoption of sustainable practices in particular (Albrecht \& Wiek, 2021), there is a lack of in-depth understanding of the most relevant factors of implementation success over time.

This gap is not surprising considering the nascent state of academic research on food forests. The majority of recent studies describe the socialcultural and environmental benefits of food forests, often through single case studies (Park \& Higgs, 2018; Riolo, 2019; Schafer et al., 2019; Wartman et al., 2018); offer insights on basic features, services, and sustainability of food forests through comparative empirical studies (Albrecht \& Wiek, 2021); or provide practical guidance on creating food forests (Bukowski \& Munsell, 2018; Remiarz, 2017). A few studies focused explicitly on success factors of implementation. A study on forest gardens in Southeast Asia and South America identified as success factors diversifying income, integrating other farming systems, choosing crops that mature within 5-10 years and are commercially valuable, as well as possessing substantial environmental knowledge and securing land tenure (Belcher et al., 2005). A recent study of 12 food forests in Sweden revealed that concepts and designs that match location, intended services, and beneficiaries are critical for developing successful food forests (Björklund et al., 2019). Furthermore, healthy soil properties, water availability, wildlife pressure, professional designs, appropriate equipment, good management practices (e.g., sufficient working hours, short distance between site and residence), and sufficiently large size (for food production) were identified as success factors, too.

An in-depth understanding of the implementation paths that food forests pursue, however, is missing. The present study attempts to bridge this 
gap by extracting factors of implementation success from a comparative study of select cases. We reconstructed the implementation paths of seven diverse food forests, mostly in Europe, with a particular focus on organization and management, based on document analysis, interviews and site visits (data were collected in 2018). The sample was composed to reflect primarily diversity in main services provided and maturity or age of the food forest.

The findings provide guidance for food entrepreneurs, public officials, and activists on how to implement sustainable food forests (or to support implementation). Therefore, we also describe common barriers that should be anticipated and planned for.

\section{Research Design}

This study uses a framework for analyzing the process and outcomes of sustainability solutions in order to identify general factors of success (Forrest \& Wiek, 2014). This framework has been applied to community development and water governance (Forrest et al., 2020; Forrest \& Wiek, 2015), and seems most applicable to sustainability solutions that are being developed and implemented over long periods of time (10 or more years), including food forests.

We selected seven food forests from a large sample of cases compiled in an inventory $(n=209)$ and from a subsample of cases we conducted detailed case studies on $(n=14)$ (Albrecht $\&$ Wiek, 2021). Of the seven selected food forests, five are in Europe (two in Germany, two in the Netherlands, and one in Portugal), one is in South America (Brazil), and one is in North America (USA). We selected the seven cases based on the following criteria: first, the cases represent a broad diversity of main service and maturity or age
(Table 1); and second, the cases are well documented through primary or secondary data. The main services consist of the common activities carried out at each food forest, with implications for organization and management (Albrecht \& Wiek, 2021). By including different age groups, we provide insights on the different practices of early pioneers versus late adopters. The Brazilian case was selected to include a mature case (over 10 years) with a focus on professional food production, which is rare in Europe and the U.S. Data on six cases is based on semistructured interviews and site visits that focused on the organization and management over the course of the implementation process (data collected in 2018). The case study on the Beacon Food Forest is based on extensive recent research by Bukowski and Munsell (2018), which provides comparable data and allows the inclusion of a successful and renowned community-based case from the U.S. The other socio-cultural cases focus on regenerative and/or educational services. By design, all food forests provide various environmental services; however, some stand out through their eco-centric design and management (e.g., limited visitor access, minimal management), such as Foodforest Ketelbroek.

We reconstructed the implementation paths of the selected seven food forests up to stable management based on primary data (observations, interviews) as well as secondary data (reports, website, etc.). We structured the implementation into a number of phases and tracked key actions, actors, and outcomes, as well as barriers and coping strategies, using standardized analytical categories developed by Forrest and Wiek (2014). For each site, we created a visual pathway and an implementation narrative.

Finally, we compared the implementation

Table 1. Overview of Food Forests Selected for this Study

\begin{tabular}{lccc}
\hline Main Services & $\begin{array}{c}\text { Young Cases } \\
<5 \text { years }\end{array}$ & $\begin{array}{c}\text { Established Cases } \\
\mathbf{5 - 1 0} \text { years }\end{array}$ & $\begin{array}{c}\text { Mature Cases } \\
>\mathbf{1 0} \text { years }\end{array}$ \\
\hline Food Production Services & Den Food Bosch (NL) & Foodforest Ketelsbroek (NL) & Fazenda Ouro Fino (BRA) \\
Social-Cultural Services & Keela Yoga Farm (PRT) & $\begin{array}{c}\text { Mienbacher Waldgarten (GER), } \\
\text { Beacon Food Forest (USA) }\end{array}$ & Essgarten (GER) \\
Environmental Services & & Foodforest Ketelsbroek (NL) & \\
\hline
\end{tabular}


paths systematically in order to generalize insights on success factors and barriers across cases, differentiated into behavioral, infrastructure, institutional, and economic factors. We pragmatically differentiate (partial) success from (partial) failure of the food forest using a set of sustainability criteria (see Table 2), developed in prior research (Albrecht \& Wiek, 2021) based on literature on sustainability (Gibson, 2006), agroforestry and food forests (Jose, 2009; Park \& Higgs, 2018), as well as expert interviews. If one or more criteria were not met at all (scoring 0), we considered the food forest to have partially failed (regarding its overall sustainability ambition) and explored the reasons for this.

\section{An Exemplary Implementation Path: Den Food Bosch, the Netherlands}

Den Food Bosch is a showcase site for regenerative food production that has operated since 2017 on 2.5 acres (1 ha) near the city of s'Hertogen- bosch, colloquially known as "Den Bosch" (population about 150,000). Its intricate food forest design (Figure 1), mostly inspired by permaculture and syntropic farming, allows harvesting on all layers (Figure 2). Produce is sold weekly on-site. Additional sales channels and processing options are currently under development.

Den Food Bosch is governed by a foundation that contracts food forest managers who are responsible for generating their income. Students from HAS University of Applied Sciences (which focuses on agricultural and food technologies, with about 3,500 students) in s'Hertogenbosch occasionally conduct research and volunteer on-site. The local water authority owns the land.

Considering its young age, Den Food Bosch already performs well with an overall average sustainability score of 1.4 out of 2 (Table 2). However, while it performs strongly on social and ecological criteria, it shows some weaknesses in the economic

Table 2. Sustainability Performance of Den Food Bosch in 2018 (2=fully met, 1=somewhat met, $0=$ =not met) Applying the Multidimensional Set of Criteria Developed in Albrecht \& Wiek (2021)

\begin{tabular}{|c|c|c|c|}
\hline & Criterion & Qualitative Assessment & Score \\
\hline \multirow{3}{*}{ 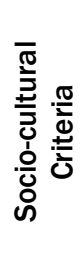 } & $\begin{array}{l}\text { Meaningful, safe employment and } \\
\text { activities with social purpose }\end{array}$ & $\begin{array}{l}\text { Pioneers in alternative biodiverse farming; high stress of start-up with } \\
\text { intensive production and without financial security }\end{array}$ & 1 \\
\hline & $\begin{array}{l}\text { Contribution to community } \\
\text { wellbeing }\end{array}$ & $\begin{array}{l}\text { Regional, seasonal, fresh and organic food supply at affordable } \\
\text { prices }\end{array}$ & 2 \\
\hline & Capacity-building & $\begin{array}{l}\text { Volunteer events for experiential learning; tours to familiarize } \\
\text { neighborhood with food forests; consultation services }\end{array}$ & 2 \\
\hline \multirow{3}{*}{ 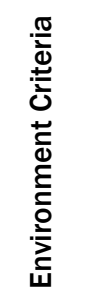 } & $\begin{array}{l}\text { Water conservation and } \\
\text { soil formation }\end{array}$ & $\begin{array}{l}\text { Close to waterways for stormwater management; developing water- } \\
\text { holding capacity } \\
\text { Mulch, organic fertilizer, and chop and drop management with } \\
\text { biomass plants }\end{array}$ & 2 \\
\hline & Cool microclimate & Young site; high layer diversity & 1 \\
\hline & High biodiversity & $\begin{array}{l}\text { High species diversity and cultivation of rare varieties; connection to } \\
\text { green corridors }\end{array}$ & 2 \\
\hline \multirow{4}{*}{ 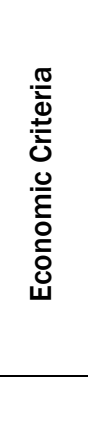 } & Economic viability & $\begin{array}{l}\text { Insufficient income from early product sales and consultation for two } \\
\text { full-time managers; lack of established sales channels or processing } \\
\text { options (leftover produce); break-even estimated after 3-4 years, high } \\
\text { profitability predicted, but no financial security for the first years }\end{array}$ & 0 \\
\hline & Formalized organization & $\begin{array}{l}\text { Foundation; evidence-based site plan; monitoring yield and } \\
\text { environmental parameters }\end{array}$ & 2 \\
\hline & $\begin{array}{l}\text { Shared ownership and decision } \\
\text { making }\end{array}$ & $\begin{array}{l}\text { Foundation with a board for long-term decision-making; land owned } \\
\text { by water authorities and leased by foundation (insecure tenure, } \\
\text { though) }\end{array}$ & 1 \\
\hline & Overall Score Average & & 1.4 \\
\hline
\end{tabular}




\section{Figure 1. The Trellis at Den Food Bosch Runs in a Semicircle Suncatch}

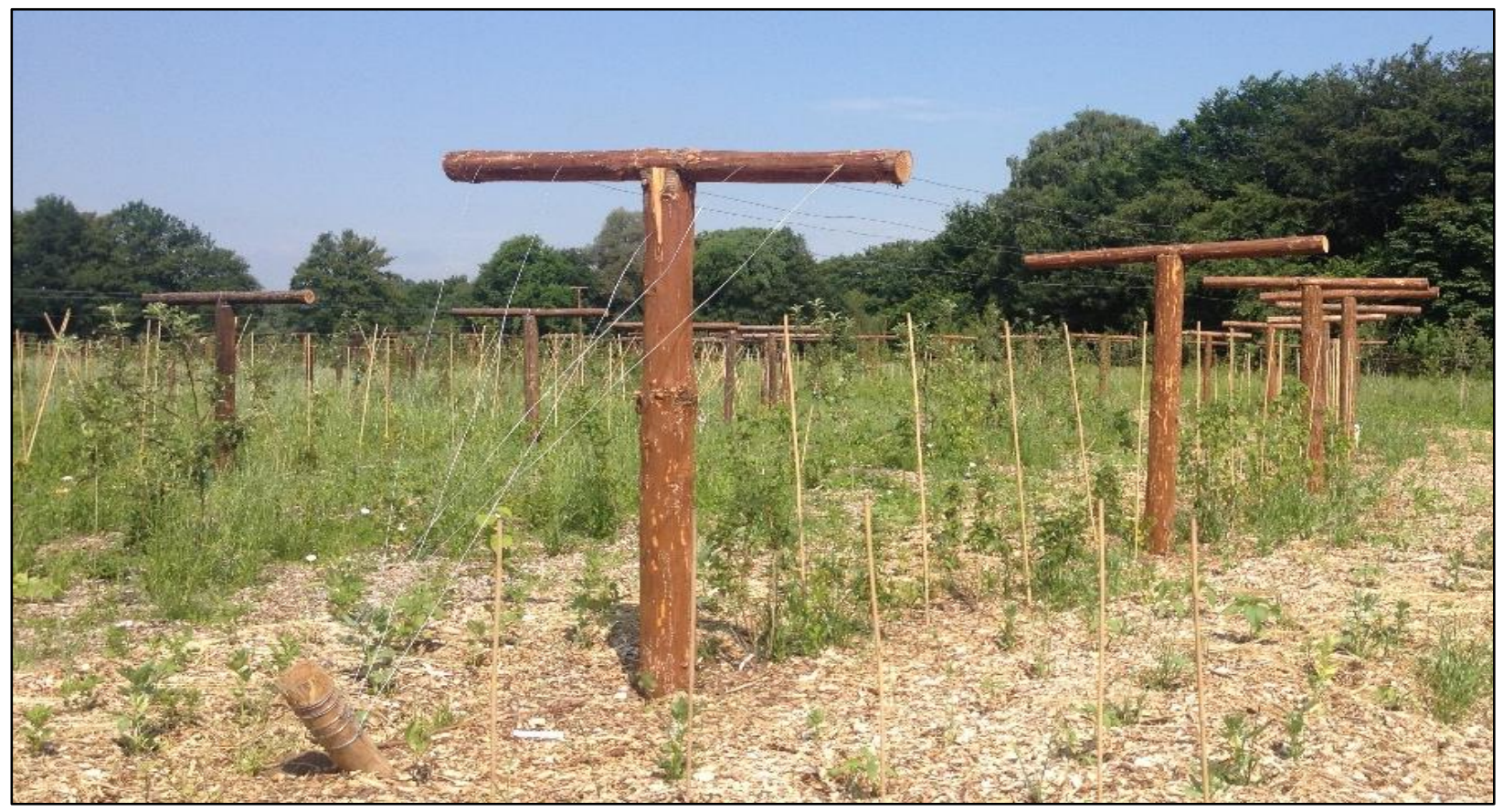

Figure 2. Den Food Bosch in 2018, Nine Months After Planting on Seven Different Layers

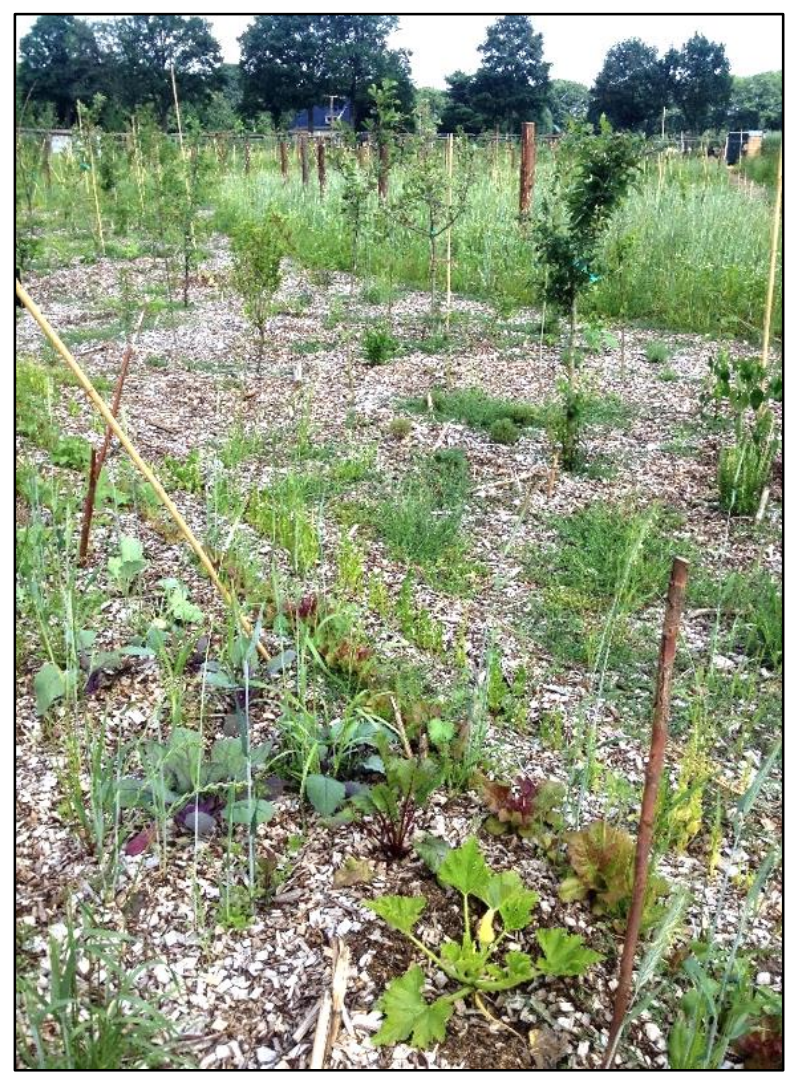

performance, especially regarding overall economic viability.

How did Den Food Bosch reach this point? What were major actions and outcomes? Who was involved? What were barriers and how were they overcome? Below, the implementation path of Den Food Bosch is described and visualized (Figure 3).

\section{Initialization Phase}

Four undergraduate students of agriculture at the HAS University of Applied Sciences started discussing food production alternatives (beyond the standard agriculture curriculum) in 2015. In fall 2016, the students organized a kick-off meeting and other events (movie nights, gardening workdays) on a potential food forest project.

\section{Planning Phase}

The students then organized additional workshops, field trips and info events, partly supported by renowned food forest experts and the university, in order to draft an initial food forest plan. As part of this effort, the core group networked and identified four potential sites for the food forest by early 2017. They eventually leased 2.5 acres (1 ha) of land in a small municipality near s'Hertogenbosch, 
owned by the local water authority. In parallel, they raised funds for materials (e.g., plants, infrastructure) from the local municipality and the AgriFood Capital Foundation. In late 2017, a forestry student with practical experience in syntropic farming completed the site design for the food forest in an undergraduate thesis.

\section{Main Implementation Phase}

The core group formed the Den Food Bosch foundation with a board advising on strategic decisions, and two of the former students started working as managers handling the daily operations of the food forest. They recruited volunteers for support, mostly from the university, and implemented the site plan between fall 2017 and spring 2018, including fence construction, mulching, and planting.
The two managers offered weekly tours to familiarize neighbors and guests with the project and to market the produce. At this early stage, the income of the managers was mostly generated through sales of annual vegetables and small consultation contracts, while additional revenue streams (e.g., produce processing, selling at farmers market) did not yet exist. The business plan, however, remained underdeveloped, and the managers faced financial insecurity, in part due to the small local consumer base. In late 2019, after 2 years of operating Den Food Bosch, the two managers quit and returned to Germany (where they started a regenerative agriculture project on a 124-acre [50-ha] site in the Pfalz). Six months later, by mid-2020, the Den Food Bosch foundation recruited two new site managers.

\section{Figure 3. Implementation Path of Den Food Bosch, 2015-2019}

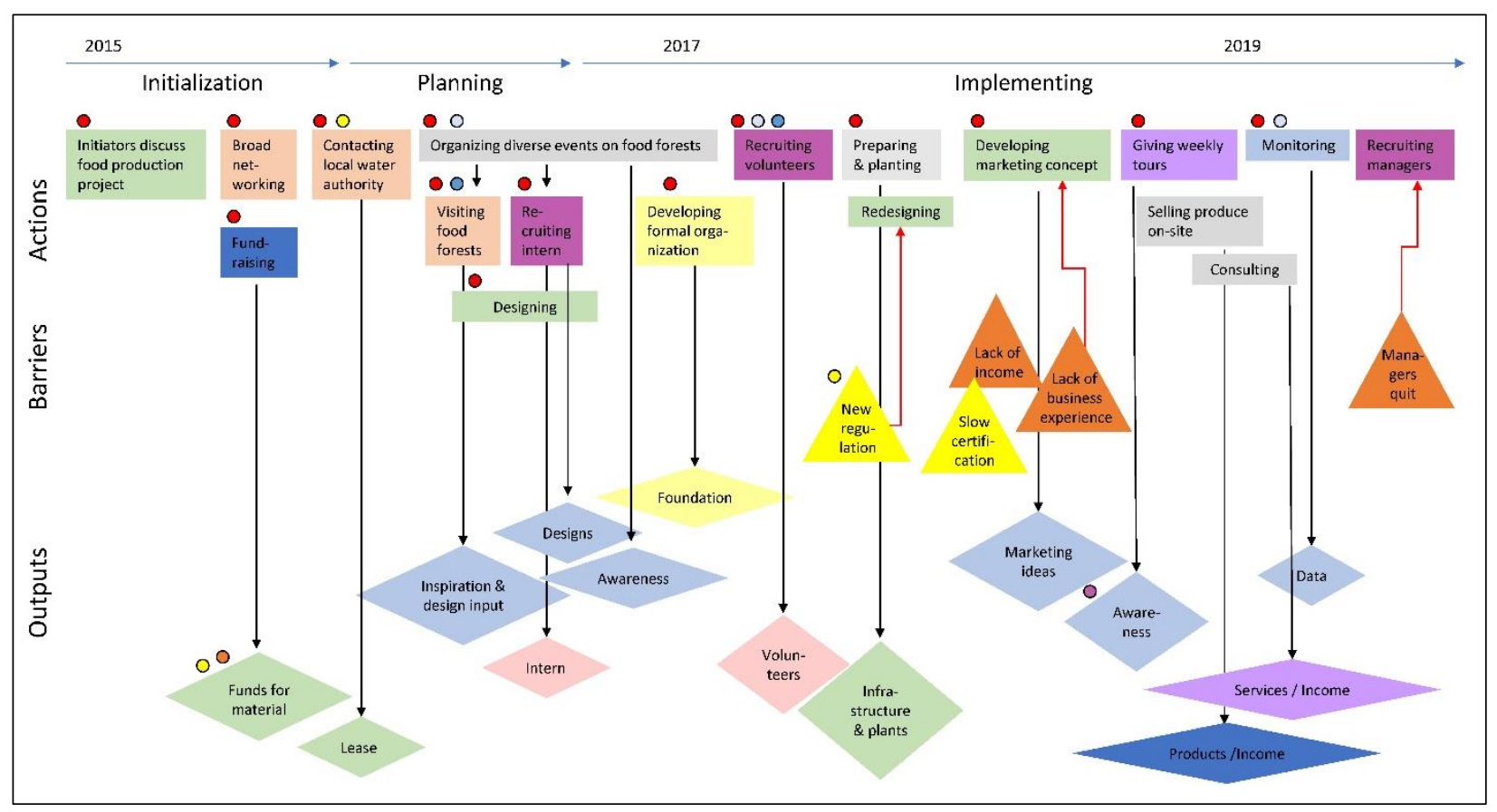

\section{Legend}

\begin{tabular}{|llll|}
\hline Actions & Actor Type & Output Type & Barrier Type \\
Networking & O Core Group & Human resources & $\Delta$ Infrastructure \\
Mobilizing & O Community Members & Services & Institutional \\
Planning & O NGOs & Infrastructure & Behavioral \\
Organizing & O Government & Institutional & Economic \\
Publicizing & O Higher Education & Knowledge & \\
Fundraising & $\bigcirc$ Business & Products & \\
Executing & & & \\
\hline
\end{tabular}




\section{Main Factors of Success}

A variety of factors enabled the implementation of Den Food Bosch. In the Netherlands, food forests are fairly well known and even legally defined for regulatory authorities. In 2018, stakeholders from government agencies, NGOs, and practitioners signed a memorandum entitled "Green Deal Food Forests" that financially supports the planning and implementation of food forests. Also, the local water authority was interested in research on waterholding capacity, and thus agreed to a favorable leasing contract. In summary, Den Food Bosch had favorable institutional conditions for implementation. In addition, the core group was made up of students/graduates from an agriculture degree program at a nearby university who had some practical experience in food forestry. This allowed for leveraging agricultural expertise (e.g., for developing the site plan and the planting), contacting food forest experts, mobilizing volunteers, accessing meeting and event spaces, and obtaining resources for planning, monitoring, and planting. Finally, the two managers dedicated a great deal of time and hard work to the project, without adequate compensation. One reason was their motivation to gain in-depth food forest experience applicable beyond Den Food Bosch (which they now leverage in their new project in the Pfalz).

\section{Main Barriers}

While Den Food Bosch was quite successfully implemented, with a fully developed food forest design in place and a good sustainability performance (Table 2), there are factors that hindered its progress. Both business and financing plans were underdeveloped, leading to a lack of sufficient income for the managers. In addition, the team encountered regulatory barriers. During the planting process, local waterway regulations changed. This required adapting the design (to increase the distance to the waterways) and accommodating management changes by the local water authority. Furthermore, pursuing organic certification was put on hold as the certification process was judged to be too timeconsuming. However, organic certification is required for sales at the organic market, which would have yielded higher profit margins. When the two managers, who had been instrumental in planning and implementing the food forest, left, Den Food Bosch lost a lot of organizational memory about site design and management.

\section{Success Factors and Barriers of Food Forest Implementation}

The reconstructed seven food forest implementation paths (similar to the example of Den Food Bosch presented in the previous section) indicate specific success factors and barriers related to organization and management for each food forest (Table 3).

From this base, we derive a set of general success factors and barriers, differentiated into behavioral, infrastructure, institutional, and economic factors (Figure 4). Despite context-specific features of each case, all cases display some of these general factors that influence their sustainability perfor-

Figure 4. Factors of Success When Implementing Food Forests

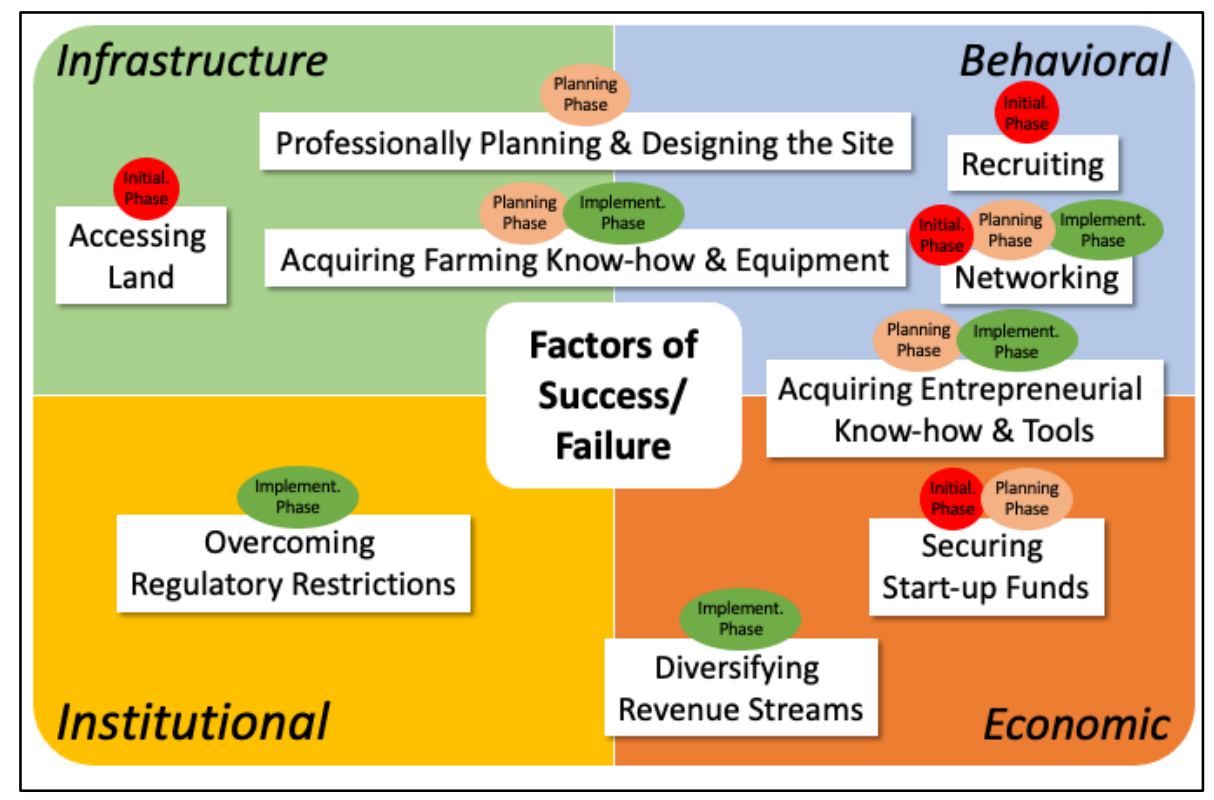


Table 3. Main Success Factors and Barriers of Implementing Food Forests

\begin{tabular}{|c|c|c|c|c|c|}
\hline $\begin{array}{l}\text { Name, Location, } \\
\text { Ownership }\end{array}$ & Start & Main Functions & Size & Success Factors & Barriers \\
\hline $\begin{array}{l}\text { Essgarten } \\
\text { Germany, metro- } \\
\text { hinterland } \\
\text { Private }\end{array}$ & 1990 & $\begin{array}{l}\text { Recreation, } \\
\text { Education } \\
\text { (Self-sufficiency) }\end{array}$ & $\begin{array}{l}6.2 \mathrm{ac} \\
2.5 \text { ha }\end{array}$ & $\begin{array}{l}\text { - Motivation related to healthy food } \\
\text { and entrepreneurial attitude } \\
\text { (experimental, creative, outgoing, } \\
\text { entertaining, caring) } \\
\text { - Land access (affordable land) } \\
\text { - Equivalent to start-up funds } \\
\text { (independent income, low costs, } \\
\text { hobby) } \\
\text { - Professional design advice } \\
\text { (landscape architect and } \\
\text { permaculture trainer) } \\
\text { - Farming know-how (gardener; } \\
\text { permaculture trainer for seminars) } \\
\text { - Entrepreneurial know-how } \\
\text { (experience gastronomy, orangery } \\
\text { for events) }\end{array}$ & $\begin{array}{l}\text { - Lack of expertise on } \\
\text { specialty plants } \\
\text { - Challenges with managing } \\
\text { volunteers } \\
\text { - Regulatory barriers } \\
\text { (gastronomy certificate) }\end{array}$ \\
\hline $\begin{array}{l}\text { Fazenda Ouro } \\
\text { Fino } \\
\text { Brazil, rural } \\
\text { Private }\end{array}$ & 1993 & $\begin{array}{l}\text { Food } \\
\text { Production, } \\
\text { Education } \\
\text { (Self-sufficiency) }\end{array}$ & $\begin{array}{l}62 \text { ac } \\
25 \text { ha }\end{array}$ & $\begin{array}{l}\text { - Motivation related to healthy food } \\
\text { and self-sufficiency } \\
\text { - Professional planning (with pilot) } \\
\text { - Farming and entrepreneurial } \\
\text { know-how (agronomy, syntropic } \\
\text { farming) } \\
\text { - Diverse revenue (high-value cash } \\
\text { crops and services) } \\
\text { - Equipment (for food processing) }\end{array}$ & $\begin{array}{l}\text { - Degraded land (former } \\
\text { pasture) } \\
\text { - Lack of staff (harvesting) } \\
\text { - Lack of practical farming } \\
\text { know-how }\end{array}$ \\
\hline $\begin{array}{l}\text { Foodforest } \\
\text { Ketelsbroek } \\
\text { Netherlands, } \\
\text { urban hinterland, } \\
\text { Private }\end{array}$ & 2009 & $\begin{array}{l}\text { Food } \\
\text { Production, } \\
\text { Education }\end{array}$ & $\begin{array}{l}5.9 \mathrm{ac} \\
2.4 \mathrm{ha}\end{array}$ & $\begin{array}{l}\text { - Motivation related to previous } \\
\text { food entrepreneurship experi- } \\
\text { ence; Network } \\
\text { - Land access (affordable land) } \\
\text { - Equivalent to start-up funds } \\
\text { (independent income, low costs, } \\
\text { earthwork funds) } \\
\text { - Farming know-how (agricultural } \\
\text { consultant, gardener) } \\
\text { - Diverse revenue (education, } \\
\text { consultancy, food), supportive } \\
\text { customers, local demand (co- } \\
\text { harvesting food businesses) }\end{array}$ & $\begin{array}{l}\text { - Degraded land (former } \\
\text { monoculture) }\end{array}$ \\
\hline $\begin{array}{l}\text { Beacon Food } \\
\text { Forest } \\
\text { USA, urban metro } \\
\text { Public }\end{array}$ & 2011 & $\begin{array}{l}\text { Community, } \\
\text { Education }\end{array}$ & $\begin{array}{l}7 \text { ac } \\
2.8 \text { ha }\end{array}$ & $\begin{array}{l}\text { Motivation related to education, } \\
\text { community building and land } \\
\text { stewardship (senior expertise, } \\
\text { long-standing involvement in } \\
\text { urban policy); Network and part- } \\
\text { nerships (access to land, grants, } \\
\text { expertise and volunteers) } \\
\text { - Professional site plan (permacul- } \\
\text { ture class, landscape architect, } \\
\text { community involvement) } \\
\text { Farming, design \& community } \\
\text { engagement know-how (land- } \\
\text { scape architecture, organic } \\
\text { farming, community projects) }\end{array}$ & $\begin{array}{l}\text { - Tenure insecurity (unspeci- } \\
\text { fied long-term agreement) } \\
\text { - Restrictive regulations } \\
\text { (e.g., water conservation, } \\
\text { land access) } \\
\text { - Loss of funds (some trees } \\
\text { dying or struggling, } \\
\text { overharvesting) }\end{array}$ \\
\hline
\end{tabular}


Table 3, continued

\begin{tabular}{|c|c|c|c|c|c|}
\hline $\begin{array}{l}\text { Name, Location, } \\
\text { Ownership }\end{array}$ & Start & Main Functions & Size & Success Factors & Barriers \\
\hline & & & & $\begin{array}{l}\text { Start-up funds ( US } \$ 135.000 \text { for } \\
\text { participatory design and initial set- } \\
\text { up) } \\
\text { - Media coverage (further funds, } \\
\text { partnerships and volunteers) } \\
\text { - Supportive regulations (urban policy } \\
\text { prioritizing tree cover and urban } \\
\text { agriculture) }\end{array}$ & \\
\hline $\begin{array}{l}\text { Den Food Bosch } \\
\text { Netherlands, urban } \\
\text { hinterland } \\
\text { Semi-public }\end{array}$ & 2016 & $\begin{array}{l}\text { Food Production, } \\
\text { Education }\end{array}$ & $\begin{array}{l}2.5 \mathrm{ac} \\
1.0 \mathrm{ha}\end{array}$ & $\begin{array}{l}\text { - Motivation related to learning and } \\
\text { demonstrating healthy food } \\
\text { production; Network (senior } \\
\text { expertise, landowners, students) } \\
\text { - Land access (collaboration with } \\
\text { local water authority) } \\
\text { - Start-up funds (for infrastructure } \\
\text { and plants) } \\
\text { - Professional site plan (student } \\
\text { thesis) } \\
\text { - Farming know-how (forestry, } \\
\text { agriculture, syntropic farming) } \\
\text { - Supportive regulations (“Green } \\
\text { Deal Food Forests") }\end{array}$ & $\begin{array}{l}\text { - Degraded land (former } \\
\text { monoculture) } \\
\text { - Lack of funds (income) } \\
\text { - Lack of practical business } \\
\text { experience } \\
\text { - Restrictive regulations } \\
\text { (e.g., certification process) }\end{array}$ \\
\hline $\begin{array}{l}\text { Keela Yoga Farm } \\
\text { Portugal, rural } \\
\text { Private }\end{array}$ & 2017 & $\begin{array}{l}\text { Education, } \\
\text { Recreation } \\
\text { (Self-sufficiency) }\end{array}$ & $\begin{array}{l}2.5 \mathrm{ac} \\
1.0 \mathrm{ha}\end{array}$ & $\begin{array}{l}\text { - Motivation related to healthy food } \\
\text { and self-sufficiency; Network } \\
\text { (work \& knowledge exchange with } \\
\text { locals, plus volunteers) } \\
\text { - Start-up funds (focused savings, } \\
\text { low costs) } \\
\text { - Professional planning (diverse } \\
\text { pilot, focused main area) } \\
\text { - Know-how in farming } \\
\text { (permaculture) and recreation } \\
\text { (yoga) } \\
\text { - Diverse revenue (yoga retreat, } \\
\text { education) }\end{array}$ & $\begin{array}{l}\text { - Learning a new language } \\
\text { - Accessing land (long } \\
\text { search, high prices) } \\
\text { - Drought } \\
\text { - Regulatory restrictions } \\
\text { (immigration) }\end{array}$ \\
\hline
\end{tabular}

mance (Wiek \& Albrecht, 2021). It is important to recognize that these factors are dependent on an existing sustainable entrepreneurial ecosystem (Cohen, 2006), which includes, among others, the availability (pool) of suitable land, financing options for sustainable businesses, and regulations favorable to agroforestry (Albrecht \& Wiek, in press). In the following, we focus on the general success factors and barriers related to organization and management, and touch on structural elements of the entrepreneurial ecosystem only in passing.

\section{Recruiting Motivated Entrepreneurs}

Motivated entrepreneurs - whether initiators or recruited ones - are the key seed for a food forest. In most cases, an individual or a small group (two to four people) starts the endeavor. Most of them live in or near the food forest and run it as a family business. Some of the food forests on public land are managed by communities (e.g., Beacon Food Forest). Food forester managers develop the food forest as fulfilling work, are keen to educate themselves and others on food, are entrepreneurial in overcoming obstacles, and are driven to contribute to a sustainable food system.

$$
\begin{aligned}
& \text { My motivation was ... when I was studying in } \\
& \text { Eberswalde international forestry ecosystem manage- } \\
& \text { ment ... we talked only about the problems .... So, }
\end{aligned}
$$




\begin{abstract}
half of the students were in a big crisis. ... I needed some kind of solution. That I want to work on something actively and I want to see that there are ways where we can actually feel like you belong to the planet, and we are not only bere to destroy it. And then, food forests were ... the answer. Because it's about how men and nature can live together and how you can live in your environment without being a nuisance. (Janine Raabe, Den Food Bosch, 2018, Figure 5)
\end{abstract}

They often hold both individualistic values of satisfying work and self-direction as well as collectivist values of public goods such as an intact environment. The economic viability of the food forest is often considered a means to fulfilling work and achieving environmental and/or social goals. Accordingly, food forests are often initiated as a hobby or side business primarily with social and environmental goals. Only later, and not in all cases, it might successively transition into professional operations. The entrepreneurs of Essgarten, for example, collected unusual edible plants for 10 years before realizing the business potential. The managers of socio-cultural food forests often have a background in health or education (e.g., physiotherapists at Essgarten; yoga teacher at Keela Yoga Farm), while managers of food forests that focus on food production often have a background in agriculture (e.g., agriculture and forestry at Den Food Bosch; agronomy and biodiversity at Fazenda Ouro Fino).

The case of Den Food Bosch shows that the loss of motivated and knowledgeable entrepreneurs during the early implementation phase (years one to three) poses a major barrier to the overall success as the first years are critical for establishing the multiple strata of the food forest (irrigate, prevent overgrowth, etc.) and laying the basis for economic viability.

\section{Accessing Land}

A major challenge for food forest initiatives is land access. Urban development pressure and high prices often lead to short-term lease contracts, small sites, or less suitable locations for food forests. Larger sites are in rural or hinterland locations, difficult to access for volunteers or guests, and often with limited access to farmers markets and other distribution locations. Innovative land access models such as land trusts or partnerships with public institutions (e.g., water authorities) or private institutions (e.g., retirement homes) can mitigate this challenge, but only to some extent. Beacon Food Forest, for example, partnered with the city of Seattle's Department of Neighborhoods to gain formal site access. However, negotiations took almost three years, and their tenure continues to be insecure. Mienbacher Waldgarten leases the land from a neighbor who runs a nursery and benefits from the produce. Although land tenure is not formally secured, there is mutual trust based on similar values regarding environmental education and edible plants. The land for Foodforest Ketelsbroek and for Keela Yoga Farm was purchased using personal savings. While this financing option secures land access, shared ownership and decision-making, such as through a land trust or an easement, would allow for more permanently securing land for regenerative agriculture in general and food forests in particular. Developing food forests as cooperative businesses could mitigate this deficit, too. Another 
common challenge is the poor soil quality at many sites, often caused by prior land use (e.g., monoculture farming, urban site). This often requires several years of remediation activities and building a healthy soil base. Several sites have water access on or close to their land (e.g., ponds, streams, well), which is crucial for establishing plants over the first few years.

\section{Securing Start-up Funds}

Most implementations of food forests lack sufficient start-up funds during the first 2 to 3 years, when infrastructure and plant set-up require investments and while revenue is very low. Common coping strategies are lowering the cost of living, using personal savings, or working at other jobs. While some food foresters are able to raise external start-up funds, they are often earmarked for infrastructure and educational events and rarely for wages. Over more than seven years, Beacon Food Forest was developed through the work of volunteers, until a registered nonprofit organization was formed and funding for two part-time positions was secured. Private funds may become available through partnerships like at Mienbacher Waldgarten, where the property owner, who is interested in the produce from the food forest, funded a seminar house. General fundraising know-how is critical for long-term implementation success, and accessing social and/or sustainable financing options (as far as there are any available) aligns the sustainability ambition of the food forests with their funding sources.

\section{Professionally Planning and Designing the Site Careful planning and site design are important success factors for food forests, in particular for those with a community orientation or aspirations for high productivity. Such planning and design can benefit from (in-kind) expert advice, student thesis projects, or stakeholder workshops. Den Food Bosch, for example, organized workshops with experts and the university community to develop a detailed site plan. Beacon Food Forest adopted a community-based planning approach, which is resource-intense but creates broad buy-in and long-term support for the food forest. For large food forests with focus on food production}

service(s), pilot projects allow for fail-safe learning as part of the implementation process. For example, Fazenda Ouro Fino and Keela Yoga Farm started with a highly biodiverse design of a small area, followed by a more efficient design with highyielding crops.

Acquiring Entrepreneurial Know-How and Tools The lack of practical business know-how, gained through experience, or resistance to conventional financial instruments (e.g., loans) commonly hinder professional implementation of food forests. Food foresters are rarely competent in business planning, fundraising, investment, bookkeeping, payroll, human resources, and marketing. Instead, motivation and activities are overly focused on the main service(s) the food forest is being developed for (food production, education, etc.), often based on personal sacrifices. To sustain livelihoods, entrepreneurial know-how is best developed prior to or very early in the implementation phase. A shift of mindset may also be required, balancing the value of biodiversity and organic development with effective and efficient design and management techniques. Some of the sampled food forests have used professional business and organizational practices to reach economic viability. The core team at Beacon Food Forest, for example, has established formal human resources procedures to train its volunteers and to deliver its workshops, which, in return, have convinced funders and secured a sufficient level of revenue. At Fazenda Ouro Fino, the focus on specialty crops, and at Essgarten on specialty events, accompanied with specific procedures and marketing, make these food forests economically viable. At Ketelbroek, keeping management costs in check secures economic viability; site maintenance requires only minimal effort at this point, and harvesting is done together with business customers.

\section{Acquiring Farming Know-How and Equipment}

Insufficient farming and food forest know-how is a common implementation challenge. The diversity of plants and services can be overwhelming, and trial and error often leads to expensive plant loss and design flaws. Lack of qualified staff hinders effective food forest implementation, too. For 
Figure 6. Henrique Souza, Fazenda Ouro Fino

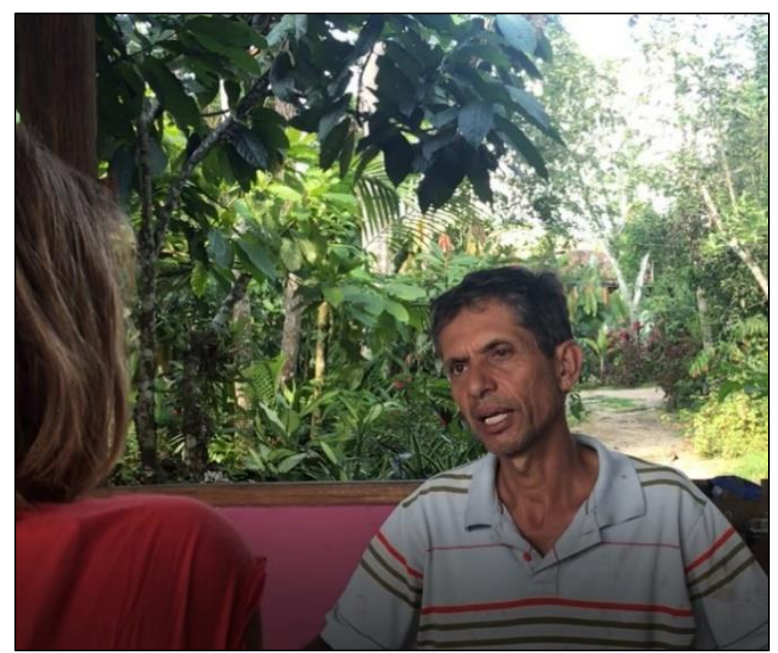

Photo: Sebastian Becker

example, Essgarten with 1,200 species requires special skills that volunteers were not able to acquire; thus, it hosted interns from an agricultural university. With increased production focus (Den Food Bosch) or diverse clients (Essgarten), skill requirements increase, which can be compensated only to some extent by creativity and perseverance.

Back in 1993, the challenges were immense. But they were important to develop our knowledge, new technologies, and ripen. The lack of knowledge was definitely the biggest challenge. We didn't know how to build the farm and had no money. There weren't any examples of a food forests in Brazil, and we were pioneers. ... But I consider the willingness-to-do as a mandatory resource. ... Now we offer 2-year courses to train professional food foresters to gain the necessary experience. (Henrique Souza, Fazenda Ouro Fino, translated, 2018, Figure 6)

Specific professional training in farming, forestry, ecology, and/or in education, social work, and design helps develop the specific services of a food forest. Expertise can also derive from personal contacts, site visits, or collaboration. Complementary to the know-how, food forests require professional equipment for the main products and services (e.g., processing machines, guest facilities) to reach economic viability. Off-grid equipment can enhance independence and minimize cost over the long term. Fences can protect young plants from wildlife. And so forth.

\section{Overcoming Regulatory Restrictions}

Restrictive policies and regulations can create major barriers for food forests. For example, food processing associated with a food forest can require certificates and safety measures that may be costly to acquire or may significantly limit the product range. Regulatory agencies often do not recognize agroforestry or food forests as a legitimate type of land use.

This was agricultural land, and my landlord said that we change this to garden land as we advertise it as a garden and have classes and people here. Then we had to have a landscape architect come here and create a plan and so on. And the requirement was that we create a compensation site. (Hannelore Zech, translated, 2018, Figure 7)

\section{Figure 7. Hannelore Zech (left) with her landlord, Mienbacher Waldgarten}

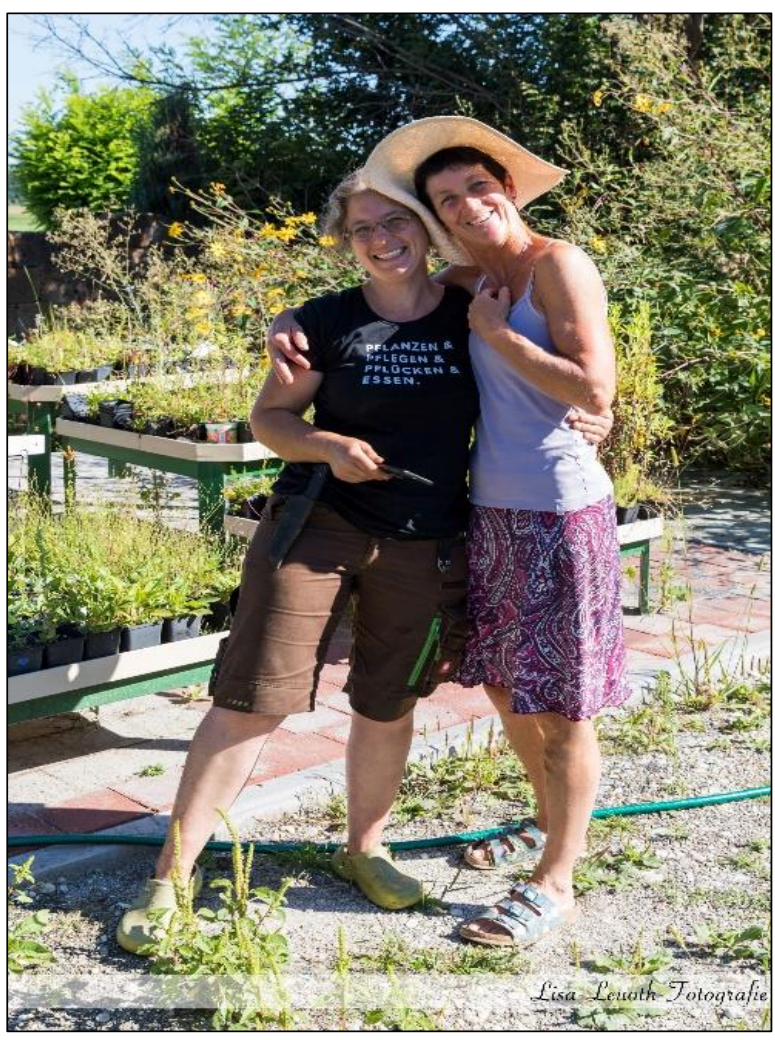

Photo: Lisa Leuoth 
Food foresters have either worked with or around governmental agencies to overcome regulatory barriers, e.g., by providing a professional site plan or installing relevant gastronomy infrastructure; or they gave up on product ideas or other non-compatible plans. The city of Seattle, on the other hand, passed a policy to allow community-led public land management, which enabled the development of Beacon Food Forest on a public site. Beacon Food Forest also benefits from Seattle's policies that prioritize tree-cover and urban agriculture and provide respective funds. Water conservation restrictions, however, still pose certain barriers, but the food forest team found creative solutions to comply with them. A broad, national policy solution has been implemented in the Netherlands, where stakeholders from government, NGOs, and practitioners signed a "Green Deal Food Forests" in 2018 to create a regulatory framework that supports implementation of food forests nationwide.

\section{Diversifying Revenue Streams}

The multitude of food forest services allows for diversifying revenue streams over time. Fazenda Ouro Fino, for example, started with specialty food items for the local and international market, but added trainings as the food forest matured and syntropic farming grew popular. Foodforest Ketelbroek started with consultation and education; later, with growing demand from the local gastronomy, food sales became a main source of revenue. Marketing, in particular through social media, is an important means to achieve diversification. At Essgarten, for example, private dinners turned into wider demand for recreational and educational events. A basket of specialty products sent to gardening magazines triggered wide media attention and broadened the customer base. Public food forests, like Beacon Food Forest, are mostly bound to acquiring public and private grants as their tenure agreements restricts regular business income generation. In this case, exploring social purpose corporation status (a legitimate corporate form in Washington state since 2012) might be a way to overcome this barrier to economic viability over the long term.

\section{Networking and Creating Strong Partnerships}

Networking and creating strong partnerships are key accompanying activities for early-stage success, for instance in accessing land and raising start-up funds, and they continue all the way into the implementation stage (e.g., for diversifying revenue). The entrepreneurs of Den Food Bosch, for example, visited many food forests to acquire know-how and develop partnerships that were later leveraged in the planning and implementation stage. Essgarten benefited from pro bono design advice by a landscape architect friend. Networking with peers is a key source of inspiration for many food forests, e.g., learning from indigenous food forests in Kenya, permaculture food forests, or Ernst Götsch's food forest. Shared values pertain to seeking solutions for a world in crisis, learning from nature (e.g., Gaia, Pachamama), and experimenting with uncommon foods.

\section{Success Factors and Barriers Mapped onto the Development Phases}

While all nine factors of success are important, independent of the food forests' main services, they come into play differently over the course of the food forest development (Figures 4 and 8). It all starts with motivated entrepreneurs, followed by securing access to land and start-up funds (Initialization). The planning phase and early implementation phase then require detailed site planning and overcoming regulatory barriers as well as acquisition of specific farming and/or food and entrepreneurial knowledge, plus infrastructure. For the main and later implementation phase, expanding and adjusting the knowledge and know-how as well as diversifying revenue streams become important factors. Networking and mobilizing support, e.g., mentorships that enable the entrepreneurs to become self-motivated and resilient, are critical activity during the entire development process.

Findings from the seven case studies suggest that economic factors are critical in each of the three stages. There is room for experiments and mistakes, but they should be limited. For example, Essgarten evolved organically without much planning (and many mistakes), but later received professional advice that improved its economic viability. Younger food forests often start with high 
Figure 8. General Development Path of Food Forests with Relevant Factors of Success

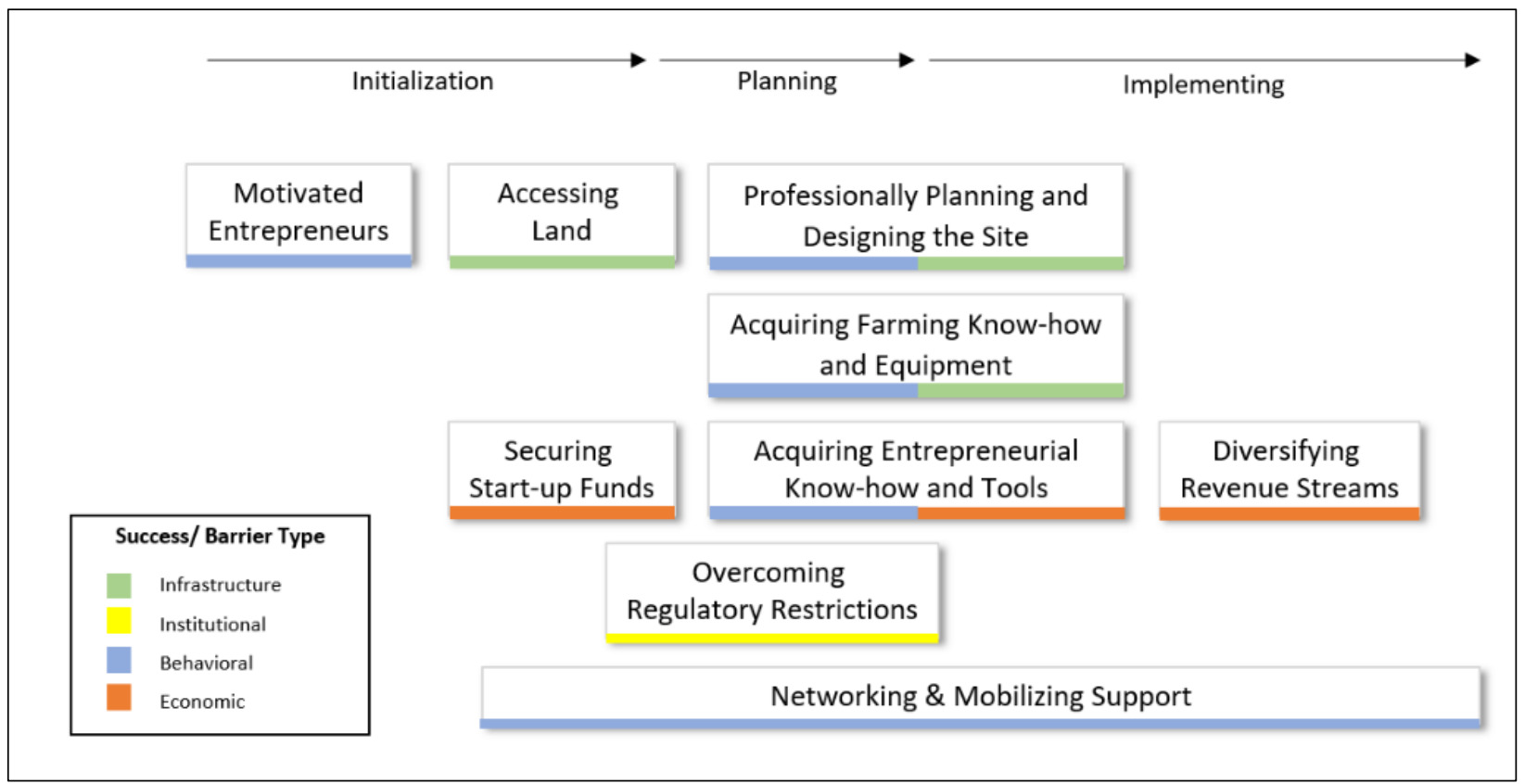

motivation and thorough designs, but to be successful, they need to advance fundraising activities and acquiring practical entrepreneurial knowhow-major barriers for many food forests. The path of Den Food Bosch exemplifies these patterns. A group of motivated agricultural students oriented toward healthy food production and business development initiated the food forest, with access to expertise and early regulative support. Initial fundraising secured land access and some limited start-up funds. The site was well planned and designed. Implementation quickly advanced due to previously acquired specific farming know-how. However, despite some business training at the university, there were gaps that prevented the development of a sustained livelihood for the main staff, which led to high stress levels. Eventually, the initiators left their positions, which casts doubt on the overall success.

\section{Discussion}

Food forest implementation is a comprehensive endeavor that depends on behavioral, infrastructure, institutional, and economic factors pertaining to organization and management. Some of these factors can be secured through general strategies such as education and training, while others call for more specific strategies such as networking with particular actor groups.

For example, similar to studies on other grassroot movements (e.g., LeBlanc et al., 2014), our findings point to the need for sustainable business training and advice in the set-up of food forests to overcome major financial barriers. In particular, entrepreneurial know-how in fundraising seems to be one critical business factor for successful implementation (Albrecht \& Wiek, 2021). Food foresters, similar to social entrepreneurs, often seem to be challenged by balancing the pursuit of the public good and paying sufficient attention to the economic viability of their enterprises (Schaltegger \& Wagner, 2011). While their reservations are well justified considering the prevalence of exploitative neoliberal business practices (e.g., profit maximization), they nevertheless demonstrate a lack of sustainable business know-how. Sustainable business models, such as cooperative businesses, social purpose enterprises, or benefit corporations, offer options for pursuing both environmental and social goals and economic viability. On the other hand, their collectivist values (e.g., intact environment, social wellbeing) allow food forest entrepreneurs to tap into resources provided through similarly collectively oriented network partnerships 
(Tiessen, 1997). Balancing both pursuits seems to be the solution here, even if that is challenging to realize.

For other success factors, such as accessing land and securing start-up funds, specific strategies need to be adopted, such as starting the food forest enterprise as a cooperative business with a broader investment base, or collaborating with NGOs that co-fund access to farmland and thus might be open to co-fund food forests (e.g., the Kulturland eG in Germany or the American Farmland Trust in the U.S.), or enabling farm succession to food foresters who are not family members. For public matters such as securing access to public land or public funds as well as coping with regulatory barriers, negotiations with local authorities or securing professional support (e.g., for licenses or site plan) might be promising strategies. These examples also point to the interdependence of success factors, in this case between these factors and networking with government agents and potential funders.

The findings confirm previous research on success factors of food forests in particular regions (Belcher et al., 2005; Björklund et al., 2019), namely the importance of specialty entrepreneurial and farming know-how, land tenure, and professional site and management plans. This study offers a more systematic exploration of the success factors and barriers covering economic, infrastructural, behavioral, and institutional factors, and mapping them over time. We found that these factors are robust across geographic regions and, for the most part, also across different services provided. Implementation paths differ in some specifics, and some factors come in earlier or later, but on a general level, all success factors are relevant to the cases studied here. Networking and creating strong partnerships should be considered a superior factor as it can facilitate securing all other success factors. Here, shared values of having a solution orientation, ecocentrism, and cultivating uncommon foods, as well as sustainable food systems in general were observed, as suggested in other studies (e.g., Wartman et al., 2018). Entrepreneurs and partners are often highly motivated by these values at the beginning; however, to ensure ongoing motivation, barriers need to be overcome and values need to be matched by sustainable practices and structures, such as through long-term land access, shared decision-making, and economic viability.

Generally, these success factors apply to most farm and food enterprises. However, since food forests pursue long-term benefits and focus on high biodiversity, they grapple with these factors in quite different ways. High start-up funds need to be secured to yield success, which then only manifests over the mid- to long-term. While food forest entrepreneurs appreciate the diverse and natural work environment they engage with, they tend to reject or underestimate the economic requirements to sustain their livelihood. Trainings in how to secure social-finance investments and how to adopt alternative (sustainable) business practices and models (e.g., cooperative businesses) may help overcome these barriers. For training in specialty farming, the challenge is often to find locally relevant information on complex plant combinations. To a certain degree, trial and error testing remains the best strategy. However, work experience at agroforestry and permaculture farms or orchards in similar climates, online or in-person training and research on perennial polycultures, and advice from specialty landscape architects can minimize the risks in designing and managing the site.

Some cases, while successful, did not exactly follow the sequence of the implementation process described above. For example, Essgarten implemented an edible homestead as a hobby first, mostly through a trial-and-error approach. It later explored site adjustments and business options when the food forest was in a mature state. While there are such successful cases based on incremental changes and iterations, they are exceptions. For most food forests, sequencing from initial conceptualization through planning and design to implementation seems a robust recipe for success. For example, the findings suggest that food forests with a focus on food production benefit from developing a professional site design (with a focus on high-value specialty crops) and a solid business plan (with direct marketing channels) at the beginning. Compared to older sites, recent start-ups thoroughly planned the implementation process with access to senior expertise (e.g., Den Food Bosch). It is promising to see how young food 
forest managers like those at Den Food Bosch adopt permaculture and syntropic farming, developed in tropical climates in the 1990s, with intricate designs for temperate climates. Furthermore, some younger food forests contribute to structural changes with more purpose-oriented forms of ownership (through foundations). A more detailed cross-case analysis of such uptakes may provide further insights into how to best advance broad adoption of these practices. The time seems ripe for more advanced pilots, such as recent crosssectoral projects in the Netherlands (Green Deal, 2020) that aim at advancing food forestry across the country through large-scale pilots, monitoring programs, and advancing recognition of food forests in government and administration.

The findings of this exploratory study are limited, primarily due to the small and diverse sample of food forests. Pragmatic sampling was required because of limited documentation, time, and financial resources. The analyzed cases are located in different regions and situated in different contexts, with preference given to Europe and North America; hence, findings cannot be generalized beyond this sample. In-depth case studies and comparative analysis should be conducted to broaden and deepen insights on entrepreneurial motivations, socialcultural backgrounds of entrepreneurs, and more, and their influence on food forest success. While this study focused on success factors directly tied to the organization and management of food forests, further studies should identify the structural elements in the entrepreneurial ecosystem that support or hinder success of food forests.

\section{Conclusions}

Food forests are differently implemented. Yet specific factors ought to be considered for each phase of the implementation, with economic factors being particularly influential on success. From early on, acquiring business and specialty farming know-how, securing start-up funds for infrastructure and staff, and securing long-term land access are the most crucial success factors. This calls for novel funding and land access schemes that support the start-up of sustainabilityoriented food forest entrepreneurship (cooperative businesses, benefit corporation, etc.) that aims at producing food and securing livelihoods, while offering social and environmental services. The long-term perspective that tree growth and generation-spanning solutions require calls for committed, purposeful partnerships that last. The success factors identified here need to be validated and nuanced through additional case studies, particularly on food forests outside Europe, and related cross-case comparisons. Complementarily, broader studies on structural factors of the entrepreneurial ecosystem need to expand this research on implementing food forests.

\section{Acknowledgments}

We would like to thank all food foresters for offering their insights in interviews and during site visits. We also would like to thank three anonymous reviewers for their constructive comments on an earlier version of this article.

\section{References}

Albrecht, S., \& Wiek, A. (2021). Food forests: Their services and sustainability. Journal of Agriculture, Food Systems and Community Development, 10(3), 91-105. https://doi.org/10.5304/jafscd.2021.103.014

Belcher, B., Michon, G., Angelsen, A., Ruiz Pérez, M., \& Asbjornsen, H. (2005). The socioeconomic conditions determining the development, persistence, and decline of forest garden systems. Economic Botany, 59(3), $245-253$. https://doi.org/10.1663/0013-0001(2005)059[0245:TSCDTD]2.0.CO;2

Björklund, J., Eksvärd, K., \& Schaffer, C. (2019). Exploring the potential of edible forest gardens: Experiences from a participatory action research project in Sweden. Agroforestry Systems, 93(3), 1107-1118. https://doi.org/10.1007/s10457-018-0208-8

Bukowski, C., \& Munsell, J. (2018). The community food forest handbook: How to plan, organize, and nurture edible gathering places. Chelsea Green Publishing.

Cohen, B. (2006). Sustainable valley entrepreneurial ecosystems. Business Strategy and the Environment, 15(1), 1-14. https://doi.org/10.1002/bse.428 
Ford, A., \& Nigh, R. (2009). Origins of the Maya forest garden: Maya resource management. Journal of Ethnobiology, 29(2), 213-236. https://doi.org/10.2993/0278-0771-29.2.213

Forrest, N., Stein, Z., \& Wiek, A. (2020). Transferability and scalability of sustainable urban water solutions-A case study from the Colorado River Basin. Resources, Conservation and Recycling, 157, Article 104790. https://doi.org/10.1016/i.resconrec.2020.104790

Forrest, N., \& Wiek, A. (2014). Learning from success-Toward evidence-informed sustainability transitions in communities. Environmental Innovation and Societal Transitions, 12, 66-88. https://doi.org/10.1016/j.eist.2014.01.003

Forrest, N., \& Wiek, A. (2015). Success factors and strategies for sustainability transitions of small-scale communitiesEvidence from a cross-case analysis. Environmental Innovation and Societal Transitions, 17, 22-40. https://doi.org/10.1016/j.eist.2015.05.005

Garnett, T. (2011). Where are the best opportunities for reducing greenhouse gas emissions in the food system (including the food chain)? Food Policy, 36(Suppl. 1), S23-S32. https://doi.org/10.1016/i.foodpol.2010.10.010

Gibson, R. B. (2006). Sustainability assessment: Basic components of a practical approach. Impact Assessment and Project Appraisal, 24(3), 170-182. https://doi.org/10.3152/147154606781765147

Green Deal Voedselbossen. (n.d.). Green Deal Voedselbossen. Retrieved 2020 from https://greendealvoedselbossen.nl

Jose, S. (2009). Agroforestry for ecosystem services and environmental benefits: An overview. Agroforestry Systems, 76(1), 1-10. https://doi.org/10.1007/s10457-009-9229-7

Konijnendijk, C. C., \& Park, H. (Eds.). (2020). Optimising urban forestry: The food connection. Burleigh Dodds Science Publishing. https://doi.org/10.19103/AS.2019.0063.19

Kumar, B. M., \& Nair, P. K. R. (2004). The enigma of tropical homegardens. Agroforestry Systems, 61, $135-152$. https://doi.org/10.1023/b:agfo.0000028995.13227.ca

LeBlanc, J. R., Conner, D., McRae, G., \& Darby, H. (2014). Building resilience in nonprofit food hubs. Journal of Agriculture, Food Systems, and Community Development, 4(3), 121-135. https://doi.org/10.5304/jafscd.2014.043.005

Lenton, T. M., Rockström, J., Gaffney, O., Rahmstorf, S., Richardson, K., Steffen, W., \& Schellnhuber, H. J. (2019, November 27). Climate tipping points—Too risky to bet against. Nature, 575(7784), 592-595. https://doi.org/10.1038/d41586-019-03595-0

Park, H., \& Higgs, E. (2018). A criteria and indicators monitoring framework for food forestry embedded in the principles of ecological restoration. Environmental Monitoring and Assessment, 190(3), Article 113. https://doi.org/10.1007/s10661-018-6494-9

Remiarz, T. (2017). Forest gardening in practice: An illustrated practical guide for homes, communities and enterprises. Permanent Publications.

Riolo, F. (2019). The social and environmental value of public urban food forests: The case study of the Picasso Food Forest in Parma, Italy. Urban Forestry \& Urban Greening, 45, Article 126225. https://doi.org/10.1016/j.ufug.2018.10.002

Rockström, J., Edenhofer, O., Gaertner, J., \& DeClerck, F. (2020). Planet-proofing the global food system. Nature Food, 1(1), 3-5. https://doi.org/10.1038/s43016-019-0010-4

Schafer, L. J., Lysák, M., \& Henriksen, C. B. (2019). Tree layer carbon stock quantification in a temperate food forest: A peri-urban polyculture case study. Urban Forestry \& Urban Greening, 45, Article 126466. https://doi.org/10.1016/j.ufug.2019.126466

Schaltegger, S., \& Wagner, M. (2011). Sustainable entrepreneurship and sustainability innovation: Categories and interactions. Business Strategy and the Environment, 20(4), 222-237. https://doi.org/10.1002/bse.682

Tiessen, J. H. (1997). Individualism, collectivism, and entrepreneurship: A framework for international comparative research. Journal of Business Venturing, 12(5), 367-384. https://doi.org/10.1016/S0883-9026(97)81199-8

Tilman, D., \& Clark, M. (2014). Global diets link environmental sustainability and human health. Nature, 515, 518-522. https://doi.org/10.1038/nature13959

Vannozzi Brito, V., \& Borelli, S. (2020). Urban food forestry and its role to increase food security: A Brazilian overview and its potentialities. Urban Forestry \& Urban Greening, 56, Article 126835.

https://doi.org/10.1016/j.ufug.2020.126835 
Wartman, P., Van Acker, R., \& Martin, R. C. (2018). Temperate agroforestry: How forest garden systems combined with people-based ethics can transform culture. Sustainability, 10(7), Article 2246. https://doi.org/10.3390/su10072246

Wiek, A., \& Albrecht, S. (in press). "Almost there"-On the importance of a comprehensive entrepreneurial ecosystem for developing sustainable urban food forests. Urban Agriculture \& Regional Food Systems. 